\title{
Effect of Different Cations on Pidan Composition and Flavor in Comparison to the Fresh Duck Egg
}

\author{
Palanivel Ganasen*, Soottawat Benjakul, and Kishimura Hideki ${ }^{1}$ \\ Department of Food Technology, Faculty of Agro-Industry, Prince of Songkla University, \\ Hat Yai, Songkhla 90112, Thailand \\ ${ }^{1}$ Laboratory of Marine Products and Food Science, Research Faculty of Fisheries Sciences, Hokkaido University, \\ Hakodate, Hokkaido 041-8611, Japan
}

\begin{abstract}
The effects of different cations on its composition and flavor characteristics of pidan white and yolk produced with duck egg in comparison to its fresh egg were investigated. Mineral content such as calcium, magnesium, sodium and potassium were significantly increased in pidan yolk irrespective of its cations in pickle solution in comparison to the fresh yolk $(P<0.05)$. It confirmed the migration of minerals from the pickling solution to the egg. However, calcium and magnesium was found lower in $0.2 \% \mathrm{PbO}_{2}$ treated pidan. Less pidan flavor compounds were generated in pidan white produced with the aid of $0.2 \% \mathrm{PbO}_{2}$. It confirmed that binding of lead prevent the maillard reaction in the pidan treated with $\mathrm{PbO}_{2}$. Benzaldehyde, ketones, alcohol and acid found in the pidan white treated with $0.2 \% \mathrm{ZnCl}_{2}$ reveals that volatiles are generated most likely from maillard reaction. However, pidan yolk of both $0.2 \% \mathrm{PbO}_{2}$ and $0.2 \% \mathrm{ZnCl}_{2}$ showed higher generation of volatiles more likely from yolk lipids. Butanal, pentanal, hexanal, and heptanal are of those aldehydes found in $0.2 \% \mathrm{ZnCl}_{2}$ treated pidan yolk whereas hexanal is the only aldehyde detected in $0.2 \% \mathrm{PbO}_{2}$ treated pidan yolk. Thus, cations in the pickling solution affect the flavor characteristics of pidan white and yolk.
\end{abstract}

Key words: pidan, flavor, volatiles, minerals, pidan yolk

\section{Introduction}

Pidans are consumed largely in many South East Asian countries, China and Korea as a pickle, and also as a side dish for congee in China and Thailand for its unique ammonia flavor (Ganesan and Benjakul, 2010). Pidan is manufactured with hen, duck or quail egg, however duck egg is most predominantly used in pidan making due to the low moisture and good flavor (Ganesan and Benjakul, 2010; Su and Lin, 1994). The formation of pidan is basically two steps denaturation and aggregation of protein; denaturation favors by soaking egg in the alkaline pickling solution and aggregation is aided by the cations incorporated in the pickling solution (Ganesan and Benjakul, 2011; Matsumura and Mori, 1996).

Denaturation and aggregation of pidan leads to generation of various peptides, aminoacids and ammonia which

*Corresponding author: Palanivel Ganasen, Department of Food Technology, Faculty of Agro-Industry, Prince of Songkla University, Hat Yai, Songkhla 90112, Thailand. Tel: 66-74-286334, Fax: 66-74-212889, E-mail: palanivel67@gmail.com results in various flavor to pidan (Chang et al., 1999). Flavor is associated with the quality of pidan, and it relies on the cations used in the pidan production. Among the ingredients used in pidan production, lead and zinc also serves as an ingredient in pidan production in the traditional process. The addition of lead or zinc at various concentrations in pickling solutions yielded the pidan with loose texture and lighter color, which might be because of the block of cations on the pores of eggshell during pickling (Ganesan and Benjakul, 2010) which may lead to the block of various flavor compounds. Flavor compound formation in the Maillard reaction depends on (1) the type of sugars and amino acids involved, and (2) on reaction temperature, time, $\mathrm{pH}$ and water content (Jousse et al., 2002). Different amino acids yields different type of flavor compounds in food products. Sulphurcontaining flavor compounds mostly derived from cysteine while the amino acid proline gives rise to typical bread, rice and popcorn flavors. The formation of flavor compounds in the Maillard reaction is very complicated and the general chemical pathways leading to classes of compounds are more or less known. 
In general, pidan white characteristic including elastic texture with ammonia and sulphur flavor is a quality index for consumers. However, a little information regarding the changes of protein structure, volatile compound generation and chemical composition of pidan white and yolk exists. Therefore, the objectives of this study were to investigate the changes in chemical composition, volatile compounds generation and microstructure of pidan white and yolk pickled with two different cations in comparison to the fresh egg.

\section{Materials and Methods}

\section{Chemicals}

Lead oxide, zinc chloride, sodium hydroxide and sodium chloride were purchased from Lab-Scan (Bangkok, Thailand). Glutaraldehyde, ethanol and silver nitrate were obtained from Merck (Darmstadt, Germany). Nile blue A was procured from Merck (Darmstadt, Germany). Purity of all salts used was greater than $99 \%$.

\section{Duck egg collection}

Fresh eggs of duck (Anas platyrhucus) with the weight range of $65-75 \mathrm{~g}$ were obtained within 1 day of laying from a farm in Rathabhum, Songhkla province, Thailand. Duck eggs were cleaned and checked for any crack prior to pickling.

\section{Preparation of pidan}

Clean duck eggs were soaked in a pickling solution containing $4.2 \% \mathrm{NaOH}, 5 \% \mathrm{NaCl}$ and divalent $(0.2 \%$ $\mathrm{ZnCl}_{2}$ ). Traditional prepared pidan using lead cations were taken as control. Eggs (60 eggs) were soaked in different pickling solutions $(6 \mathrm{~L})$ at room temperature $(30-$ $32^{\circ} \mathrm{C}$ ) for $3 \mathrm{wk}$. Pidan were removed and coated with white clay paste (clay: water, 4:1 (w/v)) to obtain a thickness of 2-3 mm. Coated eggs were left at room temperature for another three weeks for ageing and stored up to twelve weeks. During storage, the samples were taken for analyses every two week.

\section{Determination of $\mathrm{pH}$, moisture and $\mathrm{NaCl}$ contents of pidan white and yolk}

At week 6, pidan white and yolk samples with different treatments were determined for $\mathrm{pH}$ in comparison with fresh egg white and yolk according to the method of Benjakul et al. (1997). Moisture and $\mathrm{NaCl}$ contents in the pidan white samples were measured according to the method of AOAC (1995) with the analytical No. of 925.10 and 939.10, respectively. To determine salt content, sample $(1 \mathrm{~g})$ was added with $20 \mathrm{~mL}$ of $0.1 \mathrm{~N} \mathrm{AgNO}_{3}$ and 10 $\mathrm{mL}$ of $\mathrm{HNO}_{3}$. The mixture was boiled gently on a hot plate until all solids except $\mathrm{AgCl}_{2}$ were dissolved (usually $10 \mathrm{~min}$ ). The mixture was cooled using running water. Five $\mathrm{mL}$ of $5 \%$ ferric alum indicator $\left(\mathrm{FeNH}_{4}\left(\mathrm{SO}_{4}\right)_{2} \cdot 12\right.$ $\mathrm{H}_{2} \mathrm{O}$ ) were added. The mixture was titrated with the standardized $0.1 \mathrm{~N} \mathrm{KSCN}$ until the solution became permanently light brown. The percentage of salt was then calculated as follows:

$\mathrm{NaCl}$ content $(\%)=5.8 \times[(\mathrm{V} 1 \times \mathrm{N} 1)-(\mathrm{V} 2 \times \mathrm{N} 2)] / \mathrm{W}$

where $\mathrm{V} 1=$ volume of $\mathrm{AgNO}_{3}(\mathrm{~mL}) ; \mathrm{N} 1$ = concentration of $\mathrm{AgNO}_{3}(\mathrm{~N})$; V2 = volume of $\mathrm{KSCN}(\mathrm{mL})$; N2 = concentration of $\operatorname{KSCN}(\mathrm{N})$; and $\mathrm{W}=$ weight of sample (g).

\section{Determination of ammonia content of pidan white and yolk}

Ammonia content of pidan white and yolk at week 6 in comparison with fresh egg white and yolk obtained from different treatments was determined by distillation method as described by Parris and Foglia (1983) with a slight modification. Fifty $\mathrm{mL}$ of 10 -fold diluted samples were placed in a Kjeldahl flask containing $100 \mathrm{~mL}$ of distilled water and $3 \mathrm{~g}$ of $\mathrm{MgO}$. The mixture was distilled and the distillate was collected in $50 \mathrm{~mL}$ of $4 \%$ boric acid before titration with $0.05 \mathrm{M} \mathrm{H}_{2} \mathrm{SO}_{4}$ using methyl red-bromocresol green as an indicator. Ammonia content was calculated and expressed as $\mathrm{mg} / \mathrm{g}$ sample.

\section{Determination of mineral contents}

Analyses of calcium (Ca), magnesium (Mg), sodium $(\mathrm{Na})$, potassium $(\mathrm{K})$, Zinc $(\mathrm{Zn})$, lead $(\mathrm{Pb})$ iron $(\mathrm{Fe})$, copper $(\mathrm{Cu})$, Nitrogen $(\mathrm{N})$ and sulphur $(\mathrm{S})$ contents in freezedried fresh and treated pidan white and yolk were carried out using the inductively coupled plasma optical emission spectrophotometer (ICP-OES) (Model 4300 DV, Perkin Elmer, USA) according to the method of AOAC (2005). Sample $(4 \mathrm{~g})$ was mixed well with $4 \mathrm{~mL}$ of $70 \%$ nitric acid. The mixture was heated on the hot plate until digestion was completed. The digested sample was transferred to a volumetric flask and the volume was made up to 10 $\mathrm{mL}$ with deionised water. The solution was then subjected to analysis. Flow rates of argon to plasma, auxiliary and nebuliser were maintained at $15,0.2$, and $0.8 \mathrm{~L} /$ min, respectively. Sample flow rate was set at $1.5 \mathrm{~mL} /$ min. The concentration of mineral was calculated and expressed as $\mathrm{mg} / \mathrm{kg}$ sample. 


\section{Extraction of volatile compounds by SPME fibre}

To extract volatile compounds, $25 \mathrm{~g}$ of finely grounded sample was dissolved in $100 \mathrm{~mL}$ of ultra pure water. The mixture was mixed for (30 min). The supernatant $(10 \mathrm{~mL})$ was heated at $60^{\circ} \mathrm{C}$ with equilibrium time of $30 \mathrm{~min}$. Finally, the SPME fiber $\left(50 / 30 \mu \mathrm{m}\right.$ DVB/Carboxen ${ }^{\mathrm{TM}} /$ PDMS StableFlex ${ }^{\mathrm{TM}}$ ) (Supelco, USA) was exposed to the head space of the vial containing the sample extract and the volatile compounds were allowed to absorb in the SPME fiber for $30 \mathrm{~min}$. The volatile compounds were then desorbed in the GC injector port for $15 \mathrm{~min}$ at $220^{\circ} \mathrm{C}$.

\section{GC-MS analysis}

GC-MS analysis was performed in a HP 5890 series II gas chromatography coupled with HP 5972 mass selective detectors equipped with a splitless injector and coupled with a quadrupole mass detector (Hewlett Packard, USA). Compounds were separated on HP-Innowax capillary column (Hewlett Packard, USA) $(30 \mathrm{~m} \times 0.25 \mathrm{~mm}$ ID, with film thickness of $0.25 \mu \mathrm{m}$ ). The GC oven temperature program was: $27^{\circ} \mathrm{C}$ for $6 \mathrm{~min}$, followed by an increase of $3^{\circ} \mathrm{C} / \mathrm{min}$ to $135^{\circ} \mathrm{C}$, and finally an increase of $6^{\circ} \mathrm{C} / \mathrm{min}$ to a final temperature of $230^{\circ} \mathrm{C}$ and hold for $10 \mathrm{~min}$. Helium was employed as a carrier gas, with a constant flow of $1.0 \mathrm{~mL} / \mathrm{min}$. Injector was operated in the splitless mode and its temperature was set at $220^{\circ} \mathrm{C}$. Transfer line temperature was maintained at $230^{\circ} \mathrm{C}$. The quadrupole mass spectrometer was operated in the electron ionization (EI) mode and source temperature was set at $230^{\circ} \mathrm{C}$. Initially, a full scan mode data was acquired to determine appropriate masses for the later acquisition in selected ion monitoring (SIM) mode under the following conditions: mass range: $35-500 \mathrm{amu}$ and scan rate: 0.220 $\mathrm{s} / \mathrm{scan}$. All the analyses were performed with ionization energy of $70 \mathrm{eV}$, filament emission current at $150 \mu \mathrm{A}$ and the electron multiplier voltage at $500 \mathrm{~V}$.

\section{Analysis of volatile compounds}

Identification of the volatile compounds was done by consulting ChemStation Library Search (Wiley 275.L) using Probability-Based Matching (PBM) algorithm developed by Prof. Fred McLafferty and co-workers at Cornell University. The identified volatile compounds related with protein and lipid oxidation were presented in the form of normalized area under peak (\%) of each identified compound.

\section{Statistical analysis}

All experiments were run in triplicate. The experimen- tal data were subjected to Analysis of Variance (ANOVA) and the differences between means were evaluated by Duncan's New Multiple Range Test (Steel and Torrie, 1980). For pair comparison, $T$-test was used. Data analysis was performed using a SPSS package (SPSS 14.0 for Windows, SPSS Inc, USA).

\section{Results and Discussion}

\section{Changes in chemical composition of pidan white and yolk}

Changes in $\mathrm{pH}$, moisture, $\mathrm{NaCl}$ as well as ammonia content of pidan white and yolk treated with different cations were monitored in pidan in comparison with fresh egg white and yolk (Table 1). Increasing the pickling time significantly decrease the moisture content along with increase in salt and $\mathrm{pH}$ of pidan white and yolk $(p<0.05)$, regardless of type of ions used in pickling solution. Ammonia content found to be increased in pidan. The increase in $\mathrm{pH}$ and $\mathrm{NaCl}$ content indicated the migration of alkali and $\mathrm{NaCl}$ from pickling solution into egg white and yolk, respectively. Ganasen and Benjakul (2010) reported that $\mathrm{pH}$ and $\mathrm{NaCl}$ of pidan white and yolk increased during ageing irrespective of cations used in pickling solution. Moisture content loss in white and yolk of pidan mostly due to the migration of water from yolk to white and outside during increased processing time of pidan (Ganasen and Benjakul, 2010; Ganasen and Benjakul, 2011). Chi and Tseng (1998) reported that water could be migrated from egg white and egg yolk to the environment through the egg shell. This resulted in the reduction of moisture content. The lowest moisture con-

Table 1. Chemical composition of fresh and different cation treated pidan white and yolk

\begin{tabular}{cccc}
\hline \hline Parameters & Treatments & White & Yolk \\
\hline & Fresh & $8.56 \pm 0.45^{\mathrm{a}}$ & $5.90 \pm 0.25^{\mathrm{a}}$ \\
$\mathrm{pH}$ & $(0.2 \%) \mathrm{Pb0}_{2}$ & $12.68 \pm 0.03^{\mathrm{b}}$ & $10.30 \pm 0.04^{\mathrm{b}}$ \\
& $(0.2 \%) \mathrm{ZnCl}_{2}$ & $12.63 \pm 0.05^{\mathrm{b}}$ & $10.35 \pm 0.02^{\mathrm{b}}$ \\
\hline \multirow{2}{*}{ Moisture content } & Fresh & $86.52 \pm 0.51^{\mathrm{a}}$ & $44.51 \pm 0.02^{\mathrm{a}}$ \\
$(\%)$ & $(0.2 \%) \mathrm{Pb0}_{2}$ & $10.35 \pm 0.23^{\mathrm{b}}$ & $41.22 \pm 0.20^{\mathrm{b}}$ \\
& $(0.2 \%) \mathrm{ZnCl}_{2}$ & $12.03 \pm 0.42^{\mathrm{c}}$ & $37.05 \pm 0.50^{\mathrm{c}}$ \\
\hline \multirow{2}{*}{$\mathrm{NaCl}$ content } & Fresh & $0.39 \pm 0.04^{\mathrm{a}}$ & $0.47 \pm 0.03^{\mathrm{a}}$ \\
$(\%)$ & $(0.2 \%) \mathrm{Pb0}_{2}$ & $1.11 \pm 0.03^{\mathrm{b}}$ & $0.85 \pm 0.02^{\mathrm{b}}$ \\
& $(0.2 \%) \mathrm{ZnCl}_{2}$ & $1.10 \pm 0.04^{\mathrm{b}}$ & $0.80 \pm 0.04^{\mathrm{b}}$ \\
\hline \multirow{2}{*}{$\mathrm{Ammonia} \mathrm{content}$} & Fresh & $\mathrm{ND}$ & $\mathrm{ND}$ \\
$(\%)$ & $(0.2 \%) \mathrm{Pb0}_{2}$ & $0.25 \pm 0.02$ & $0.18 \pm 0.02$ \\
& $(0.2 \%) \mathrm{ZnCl}_{2}$ & $0.31 \pm 0.01$ & $0.21 \pm 0.01$ \\
\hline
\end{tabular}

Values are mean \pm standard deviation $(n=3)$.

${ }^{\mathrm{a}, \mathrm{b}}$ Different letters in the same column within the same parameter indicate the significant differences $(P<0.05)$. ND $=$ Not detectable 
tent found in the white of pidan treated with $0.2 \% \mathrm{PbO}_{2}$ was probably resulted from a greater interaction of white proteins induced by lead ion. Ammonia was formed in the pidan white, and yolk possibly by deamination process (Hou, 1981). Deamidation of proteins occurs at $\mathrm{pH}$ above 8.0, dependent upon the $\mathrm{H}^{+}$or $\mathrm{OH}^{-}$concentration and adjacent amino acid residue (Riha et al., 1996). Higher ammonia content was found in pidan white treated with $0.2 \% \mathrm{ZnCl}_{2}$ treated pidan confirm that higher deamination of pidan white and yolk during production of pidan. Thus cations influence the che- mical composition of pidan white and yolk.

\section{Changes in mineral content of pidan white and yolk}

The freeze-dried fresh egg white and yolk and cation treated pidan white and yolk consisted of different minerals at different levels, as shown in Table 2 and Table 3. The increase in mineral content of pidan white and yolk indicated the migration of mineral from pickling solution into egg white and yolk, respectively. It was coincide with increase in $\mathrm{pH}$ and of pidan white and yolk. The high content of $\mathrm{Na}$ ( 2.1 to $2.2 \%$ ) of pidan white and yolk indicate that greater migration of sodium from pickling solution. Sulphur content found to be retained in $0.2 \% \mathrm{PbO}_{2}$ treated pidan white (Table 2) most likely involves in the interaction with lead. Dunham (1972) reported that lead has a strong affinity for some ligands, including the epsilon amino group of lysine, the carboxyl group of glutamic and aspartic acids, the sulfhydryl group of cysteine. Addition of cation such as lead and zinc in the pickling solution also involves in the migration of cations to the pidan white and yolk. It was evidenced that $0.2 \% \mathrm{ZnCl}_{2}$ treated pidan white shows higher amount of zinc (Table 3 ). However, the rate of migration varies with the type of cations

Table 2. Mineral content of fresh and cation treated pidan white

\begin{tabular}{cccc}
\hline \hline & \multicolumn{3}{c}{ White $(\mathrm{mg} / 100 \mathrm{~g})$} \\
\hline Minerals & Fresh & $(0.2 \%) \mathrm{Pb}_{2}$ & $(0.2 \%) \mathrm{ZnCl}_{2}$ \\
Calcium & 23.12 & 19.4 & 29.2 \\
Magnesium & 79.89 & 19.94 & 28.89 \\
Sodium & 754 & 2192.9 & 2250.9 \\
Potassium & 604.4 & 878.15 & 748.6 \\
Zinc & $\mathrm{ND}^{\mathrm{a}}$ & 0.56 & 2.63 \\
Lead & $\mathrm{ND}^{\mathrm{a}}$ & $<0.5^{\mathrm{b}}$ & $\mathrm{ND}$ \\
Copper & 0.79 & 0.52 & 0.35 \\
Iron & 1.11 & 2.33 & 2.19 \\
Nitrogen & 12.86 & 13 & 12.68 \\
Sulphur & 1.7 & 1.4 & 1.17 \\
\hline
\end{tabular}

${ }^{a} \mathrm{ND}$ : Not detectable

${ }^{\mathrm{b}}$ Expressed as \% $(\mathrm{mg} / \mathrm{Kg})$ used in pickling solution. Higher amount of minerals present in the pidan white than yolk confirm that minerals are retained in white protein during pickling of pidan. Increase and decrease of other minerals indicate that migration of minerals takes place from pickling solution through white to yolk or vice versa. Thus cations and minerals in pickling solution enhance the amount of mineral in the pidan.

\section{Effect of cations on the formation of volatile flavors in the pidan yolk and white}

Formation of volatile flavors from pidan white and yolk obtained at week 6 of ageing is shown in Table 4. Different cation treatment results in the different in flavor of pidan white and yolk. In general pidan yolk, yielded more volatiles than pidan white most likely contributes from the yolk lipids. Alkali penetration along with cations causes higher release of free lipid from the bound protein (Ganasen and Benjakul, 2010). Oxidation of PUFAs is known to produce volatile aldehyde compounds including haxanal, heptanal, octanal, etc (Yasuhara and Shibamoto, 1995). Aldehydes are the most prominent volatiles produced during lipid oxidation and have been used successfully to follow lipid oxidation in a number of foods, including muscle foods (Ross and Smith, 2006). Butanal pentanal, hexanal and heptanal are of those aldehydes found in $0.2 \% \mathrm{ZnCl}_{2}$ treated pidan yolk whereas hexanal is the only aldehyde can detect in $0.2 \% \mathrm{PbO}_{2}$ treated pidan yolk. Aldehydes have been used as the indicators of lipid oxidation because they possess low threshold values and are the major contributors to the development of odor (Ross and Smith, 2006). Higher percentage of normalized peak area of hexanal was found in $0.2 \% \mathrm{ZnCl}_{2}$ treated pidan yolk than in $0.2 \% \mathrm{PbO}_{2}$ (Table 4). Aldehydes generated from oxidation reactions of fatty acids are frequently rela-

Table 3. Mineral content of fresh and cation treated pidan yolk

\begin{tabular}{cccc}
\hline \hline & \multicolumn{3}{c}{ Yolk $(\mathrm{mg} / 100 \mathrm{~g})$} \\
\hline Minerals & Fresh & $(0.2 \%) \mathrm{Pb}_{2}$ & $(0.2 \%) \mathrm{ZnCl}_{2}$ \\
Calcium & 158.22 & 186.88 & 307.84 \\
Magnesium & 18.23 & 27.18 & 25.22 \\
Sodium & 72.3 & 711.2 & 1516.81 \\
Potassium & 131.42 & 212.87 & 246.67 \\
Zinc & 3.95 & 3.03 & 3.75 \\
Lead & $\mathrm{ND}^{\mathrm{a}}$ & $<0.5^{\mathrm{b}}$ & $\mathrm{ND}$ \\
Copper & 0.14 & 0.16 & 0.34 \\
Iron & 8.51 & 7.38 & 6.63 \\
Nitrogen & 4.91 & 5.36 & 5.32 \\
Sulphur & 0.28 & 0.29 & 0.29 \\
\hline
\end{tabular}

${ }^{\mathrm{a}} \mathrm{ND}$ : Not detectable

${ }^{\mathrm{b}}$ Expressed as \% $(\mathrm{mg} / \mathrm{Kg})$ 
Table 4. Volatile compounds identified in the HS-SPME-GC/MS(SPME FIBRE) profile of pidan white and yolk

\begin{tabular}{|c|c|c|c|}
\hline Treatments & Compounds & $\begin{array}{l}\text { Retention time } \\
\text { (min) }\end{array}$ & $\begin{array}{c}\text { Normalized Peak } \\
\text { area (\%) }\end{array}$ \\
\hline \multicolumn{4}{|c|}{ Pidan white $\left(0.2 \% \mathrm{ZnCl}_{2}\right)$} \\
\hline & Butanal & 4.08 & 10.39 \\
\hline & Benzene & 8.12 & 18.83 \\
\hline & Dimethysilooxane pentamer & 16.66 & 7.58 \\
\hline & 2-Nonanone & 24.65 & 22.09 \\
\hline & Cyclohexasilooxane,dodecamethyl-CAS & 24.8 & 19.67 \\
\hline & 1-hepten-3-ol & 27.7 & 13.71 \\
\hline & Benzaldehyde & 30.29 & 7.73 \\
\hline & 2-undecanone CAS & 33.42 & 10.39 \\
\hline & Cyclopentasilooxane, decamethyl-CAS & 38.44 & 18.83 \\
\hline & Benzeneacetic acid & 43.7 & 7.58 \\
\hline \multicolumn{4}{|c|}{ Pidan white $\left(0.2 \% \mathrm{PbO}_{2}\right)$} \\
\hline & Methane dichloride & 4.08 & 5.22 \\
\hline & 1,3,5-cycloheptatriene & 7.24 & 8.92 \\
\hline & Cyclotetrasilooxane, octamethyl-CAS & 7.82 & 14.59 \\
\hline & Cyclopentasilooxane,decamethyl-CAS & 16.45 & 7.88 \\
\hline & Cyclopentasilooxane, dodecamethyl-CAS & 24.72 & 9.62 \\
\hline & 1,1,3,3,5,5,7,7,9,9,11,11-dodecamethyl-Hexalsilooxane & 31.94 & 5.4 \\
\hline & Silane & 38.48 & 4.4 \\
\hline \multicolumn{4}{|c|}{ Pidan yolk $\left(0.2 \% \mathrm{ZnCl}_{2}\right)$} \\
\hline & Butanal & 4.05 & 1.08 \\
\hline & Pentanal & 5.8 & 1.16 \\
\hline & Cyclotetrasilooxane, octamethyl-CAS & 8.26 & 2.51 \\
\hline & Hexanal & 10.2 & 54.51 \\
\hline & Heptanal & 15.1 & 2.02 \\
\hline & Cyclopentasilooxane,decamethyl-CAS & 16.71 & 9.43 \\
\hline & 4 amino-5-imidazole Carboxamide,TrisT(Trismethylsilyl) & 24.76 & 3.71 \\
\hline & Allyl urea & 24.92 & 1.48 \\
\hline & 1-Penten-3-ol & 27.7 & 10.33 \\
\hline & Furan,2,5 dihydro-(CAS) & 29.12 & 3.13 \\
\hline & Pregna-5-16-dien-20-one & 31.93 & 4.07 \\
\hline & Tetracosamethylcyclododecasilooxane & 38.47 & 2.54 \\
\hline & Benzeneacteicacid, alpha 3,4.tris & 43.72 & 1.02 \\
\hline \multicolumn{4}{|c|}{ Pidan yolk $\left(0.2 \% \mathrm{PbO}_{2}\right)$} \\
\hline & Methane dichloride & 4.56 & 3.58 \\
\hline & Cyclotetrasilooxane, octamethyl-CAS & 8.27 & 3.75 \\
\hline & Dimethyldisulphide & 9.62 & 3.5 \\
\hline & Hexanal & 10.17 & 16.8 \\
\hline & Benzoic acid & 16.56 & 8.05 \\
\hline & 1-pentanol CAS & 18.95 & 2.68 \\
\hline & 1-Pentene & 23.47 & 19.25 \\
\hline & Hexadecanoicacid & 24.73 & 7.31 \\
\hline & Cyclopropane & 26.24 & 3.45 \\
\hline & 2-Butenol & 27.68 & 14.76 \\
\hline & Octylpropylsulphide & 27.81 & 2.12 \\
\hline & $1 \mathrm{H}$-purin-6-amine & 38.44 & 4.33 \\
\hline
\end{tabular}

ted with the off-odours (McGill et al., 1974). Thus 0.2\% $\mathrm{PbO}_{2}$ treated pidan yolk help in the prevention of lipid oxidation byproducts.

Alcohols, acids and ketones were also detected in pidan yolk treated with both cations. Alcohols were the secondary products produced by the decomposition of hydroperoxide (Girand and Durance, 2000). Ketone is another se- condary lipid oxidation product derived from the decomposition of hydroperoxide. In general, the lower amount of secondary oxidation products including aldehydes, alcohols and ketones in the $0.2 \% \mathrm{PbO}_{2}$ confirm that lead binding lowered the oxidation in yolk of pidan. Some sulfide compound detected in the yolk of pidan treated with $0.2 \% \mathrm{PbO}_{2}$ confirm that lead binding helps in the retain- 
ing of sulphur in yolk. Furan compounds such as (Furan, 2,5 dihydro-(CAS)) is detected in $0.2 \% \mathrm{ZnCl}_{2}$ treated pidan yolk. 2-ethylfuran is formed by the decomposition of 12-hydroperoxide of linolenate (18:3n-3), the 14-hydroperoxide of eicosapentaenoate (20:5n-3) and the 16-hydroperoxide of docosahexaenoate (22:6n-3), which can undergo $\beta$-cleavage to produce a conjugated diene radical which can react with oxygen to produce a vinyl hydroperoxide. Cleavage of the vinyl hydroperoxide by loss of a hydroxyl radical forms an alkoxyl radical, that undergoes cyclisation, thus producing 2-ethylfuran (Medina et al., 1999). Thus, the $0.2 \% \mathrm{PbO}_{2}$ was found to be effective in retarding the formation of secondary lipid oxidation products in pidan yolk during pidan production.

Type of volatile compounds found in pidan white was fewer than pidan yolk. Pidan white volatiles are more likely contribute from the maillard reaction. Maillard reaction favors at the alkaline $\mathrm{pH}$ of pidan white (Ganasen and Benjakul, 2011). At the final stage of Maillard reaction, the reactive dicarbonyl again react with free amino groups and through oxidation, dehydration and cyclization reactions, form aldehyde, ketones, pyrazines and color compounds, usually called Advanced Glycation End-Products (AGEs) (Baynes and Thorpe, 1999). Some AGEs such as pyrroles, pyrazines contribute to the volatile compounds responsible for flavor (Ho, 1996). Benzaldehyde, ketones and alcohol and acid are found in the pidan white treated with $0.2 \% \mathrm{ZnCl}_{2}$ with lower percentage of normalized peak area revealed that volatiles are generated most likely from maillard reaction. However no such compounds seen in the pidan treated with $0.2 \% \mathrm{PbO}_{2}$ confirms that lead binding may inhibit Maillard reaction and oxidation of protein which may contribute to such volatiles in pidan. In our previous study, sensory score of pidan white treated with $0.2 \% \mathrm{ZnCl}_{2}$ showed lower likeness score due to loosen textures which favor higher mailliard reaction of the pidan white than in $0.2 \% \mathrm{PbO}_{2}$ treated pidan white (Ganesan and Benjakul, 2012). Thus maillard reaction enhances in $0.2 \% \mathrm{ZnCl}_{2}$ treated pidan white which may lead to different volatile flavors in pidan.

In conclusions, comparative study on the flavor characterestics of pidan produced with different cation reveals that $0.2 \% \mathrm{PbO}_{2}$ treated pidan white produce less volatile flavor compounds and higher crosslinking of protein than pidan white produce from $0.2 \% \mathrm{ZnCl}_{2}$. However, volatile compound generation enhanced in both treatment of pidan yolk most likely due to the lipid naturally present in yolk. Thus cations in the pickling solution affect the fla- vor characteristics of both pidan white and yolk due to the difference in pidan gel formation with the aid of cations.

\section{Acknowledgements}

The authors would like to express their sincere thanks to Graduate School of Prince of Songkla University for the financial support.

\section{References}

1. AOAC (1995) Official Method of Analysis. 16th ed, Association of Official Method of Analytical Chemists, Washington, DC, p. 42.

2. AOAC (2005) Official Method of Analysis. 18th ed, Association of Official Method of Analytical Chemists, Washington, DC, pp. 4-56.

3. Baynes, J. W. and Thorpe, S. R. (1999) Role of oxidative stress in diabetic complications: A new perspective on an old paradigm. Diabetes 48, 1-9.

4. Benjakul, S., Seymour, T. A., Morissey, M. T., and An, H. (1997) Physicochemical changes in Pacific whiting muscle proteins during iced storage. J. Food Sci. 62, 729-733.

5. Chang, H. M., Tsai, C. F., and Li, C. F. (1999) Quantification of racemization of amino acids in alkali-treated duck eggs by micellar capillary electrophoresis. J. Agric. Food Chem. 47, 479-484.

6. Dunham, C. L. (1972) Lead. Airborne lead in perspective. Committee on biologic effects of atmospheric pollutants. Natl. Acad. Sci. Publ.

7. Ganasen, P. and Benjakul, S. (2010) Physical properties and microstructure of pidan yolk as affected by different divalent and monovalent cations. LWT-Food Sci. Technol. 43, 77-85.

8. Ganasen, P. and Benjakul, S. (2011) Physical properties and microstructure of pidan white as affected by different divalent and monovalent cations. J. Food Biochem. 35, 1528-1537.

9. Ganesan, P. and Benjakul, S. (2013). Effect of glucose treatment on texture and color of pidan white during storage. $J$. Food Sci. Technol. Mysore (In press).

10. Girand, B. and Durance, T. (2000). Headspace volatiles of sockeye and pink salmon as affected by retort process. J. Food Sci. 65, 34-39.

11. Ho, C. T. (1996) Thermal generation of Maillard aromas. In: The Maillard reaction. Consequences for the Chemical and Life Sciences. Raphael, I. (ed) Wiley \& Sons, Chischester, England, pp. 27-53.

12. Hou, H. C. (1981) Egg preservation in China. Food and Nutrition Bulletin. The United Nations University Press, Tokyo.

13. Jousse, F., Jongen, W., Agterof, W., Russell, S., and Braat, P. (2002) Simplified kinetic scheme of flavour formation by the Maillard reaction. J. Food Sci. 67, 2534-2542.

14. Matsumura, Y. and Mori, T. (1996) Gelation. In: Methods to Testing Protein Functionality. Hall, G.M. (ed) Chapmen \& Hall, London, pp. 76-109. 
15. McGill, A. S., Hardy, R., Burt, J. R., and Gunstone, F. D. (1974) Hept-cis- 4-enal and its contribution to the off-flavour in cold stored cod. J. Sci. Food Agric. 25, 1477-1489.

16. Medina, I., Satue-Gracia, M. T., and Frankel, E. N. (1999) Static headspace-gas chromatography analysis to determinate oxidation of fish muscle during thermal processing. J. Am. Oil. Chem. Soc. 76, 231-236.

17. Parris, N. and Foglia, T.A. (1983) Simplified alcoholic extraction for ammonia in meat tissue. J. Agric. Food Chem. 31, 887-889.

18. Riha, W. E. III., Izzo, H. V., Zhang, J., and Ho. C. T. (1996) Nonenzymatic deamidation of food proteins. Crit. Rev. Food
Sci. Nutr. 36, 225-255.

19. Ross, C. F. and Smith, D. M. (2006) Use of volatiles as indicators of lipid oxidation in muscle foods. Compr. Rev. Food Sci. Food Saf. 5, 18-25.

20. Steel, R. G. D. and Torrie, J. H. (1980) Principles and procedures of statistics. McGraw-Hill Book Co., New York, pp. 106-107.

21. Su, H. and Lin, C. W. (1994) Effect of processing condition on the formation of lysinoalanine in duck pidan. J. Chin. Soc. Anim. Sci. 23, 323-330.

(Received 2012.10.31/ Revised 2013.02.12/Accepted 2013.3.23) 